\title{
Quality in education and training in photonics in the Netherlands
}

\section{P. Stroobach, Ivar Boerefijn}

P. Stroobach, Ivar Jacco Boerefijn, "Quality in education and training in photonics in the Netherlands," Proc. SPIE 3190, Fifth International Topical Meeting on Education and Training in Optics, (8 December 1997); doi: $10.1117 / 12.294390$

Event: Fifth International Topical Meeting on Education and Training in Optics, 1997, Delft, Netherlands 
Quality in Education and Training in Photonics in the Netherlands

\author{
P.Stroobach \\ Prof.Zeemanstraat 25 \\ 2041 CN Zandvoort
}

\author{
I.J.Boerefijn \\ Beukenstuklaan 49 \\ 3903 DN Veenendaal
}

Both P. Stroobach and I.J. Boerefijn are students at The Rijswijk Institute of Technology (THR) in the area of applied physics with the specialisation of photonics. Before this school they both went to the Technisch College Ede (TCE) and graduated as opto-technician for the theoretical part in 1994.

Both are heavily involved in the fraternity of physics 'Ångström' at the THR. Because of their activities they were asked by the Dutch Society of Optics to organize and to carry out this survey.

\begin{abstract}
The object of this study was to find the connection of photonic training in the Netherlands between the participating schools and the trade and industry.

The Dutch Society of Optics did an enquiry into the quality of photonic education at the MBO/HBO Level during the period of November 1996 till July 1997. The research was about the connection of the schools which educate photonics and the trade and industry.

The main target of the research is to have a better understanding of the quality of the connection. Both from a students and/or graduate point of view as well as from a trainee mentors one. This research was strongly supported by the schools in the Netherlands who teach this kind of education.

The way of research was by poll, which is held under a population of students and graduated people which at least had been in contact with the trade and industry in the area of photonics and there mentors
\end{abstract}

Keywords in this survey are: student and/or graduate, mentor, school, trade and industry, quality

\title{
2. INTRODUCTION
}

Because of the 50th birthday of the ICO and the "Fifth International Topical Meeting on Education in Optics" the Dutch Society of Optics and Photonics (NVvF) has decided to conduct a survey to the schools which educate photonics at the $\mathrm{MBO} / \mathrm{HBO}$ level.

\section{PURPOSE}

The main purpose of the survey is to look at the connection between the trade and industry and the photonic educating institutes in The Netherlands at the MBO/HBO level. A number of years ago there was a similar inquiry held among people who work in the photonic area [2]. Together these two survey's give a good view at the photonic eduqations in the Netherlands. 
A number of years ago, after discussion between some institutes and the trade an industry, the need for photonic education was emerced. Since that period a number of educations are esthablished. At the THR in 1988 the qraduation direction photonics added to the study of applied physics. At the Leidse Instrumentmakers School (LIS) there was already a study to optical technician there is a follow up study in lasertechnics arrised. The TCE has since 1990 an opto-technician education.

Since 1996 the section Electrotechnics/Telematics of the Hoge School Utrecht has added a graduation variant Medical Technics which it's aims at röntgen techniques.

The fraternity of physics 'Ångström' at the THR has preformed this survey.

\section{MAIN TARGET}

The researched group consisted of students, graduated and trainee mentors. For the students it is requered they have been in contact with the trade and industry. There are no students of te Hogeschool Utrecht which fit in the profile

\section{METHOD OF INQUIRY}

After a discussion with the coöperating institutes, the method which is chosen is a poll. The authors made two kinds of poll-forms. The first is ment for the students and graduates, the second for their mentors. A mentor supports the student during trainee or graduating period. After approval by the institutes, the forms were spread. The poll consists of three parts, theyare:

- questions about the photonic backround, think off: eduqation, trainee and work enviroment.

- questions about the connection between education and the trade and industry.

- a possibility to give suggestions

\section{RESULTS}

In this chapter we first explain the used terms. Than we print the asked questions with it's results. And at last we print the main topics from the given suggestions.

The used terms:

Photonic subjects

includes subjects like optics, lasertechnics, machine vision and opto-electronics.

Other technical subjects : include things like physics, mathematics, electronics and chemistry.

Not technical subjects $\quad$ : includes subjects like Dutch, English, social science, science philosophy

Communicative subjects $\quad$ : training in reporting, presentations, meetings and applications 
For the questions there where five possible choices.

good

satisfying

moderate

insufficent

bad
: the level is excelent, the highest possible judgement : the level is sufficient : the level is below what is expected, but just enough : the level is below is not good enough : the level is hilarious

\subsection{Student/graduate form (MBO)}

question 1: Give a judgement of the given skills at the last followed "photonic" education.

Quention 1: Theorotled subject:

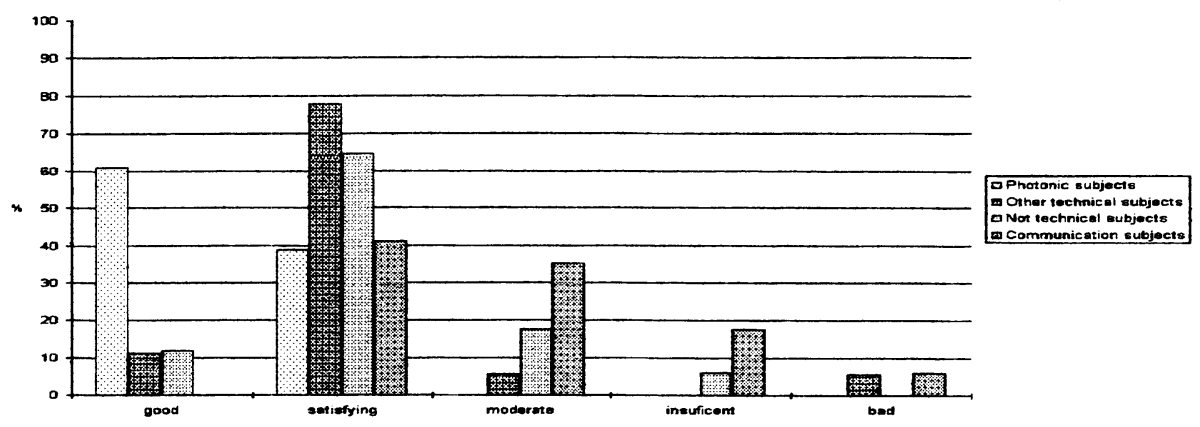

Question 1: Practloal subjocte
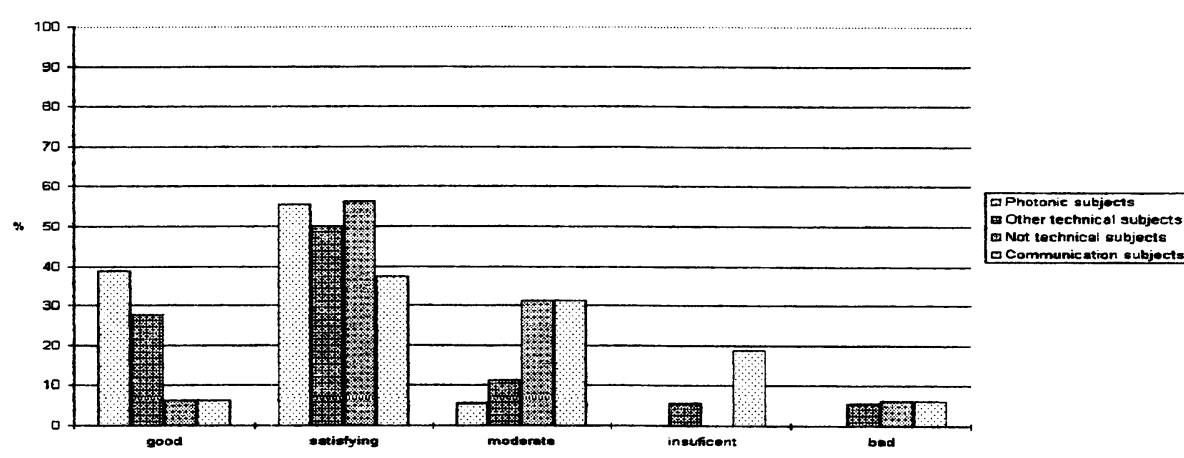

Other tectrical subjects

Q Not tochnical subjects
CCommunic ation subjects

question 2: Which skills fit in with the trainee period, graduation period an during work.

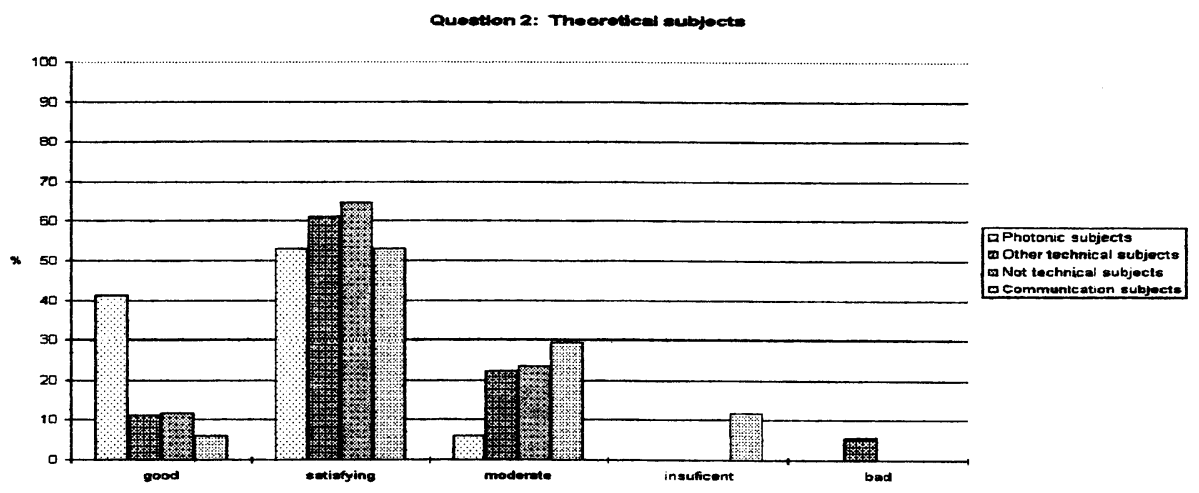




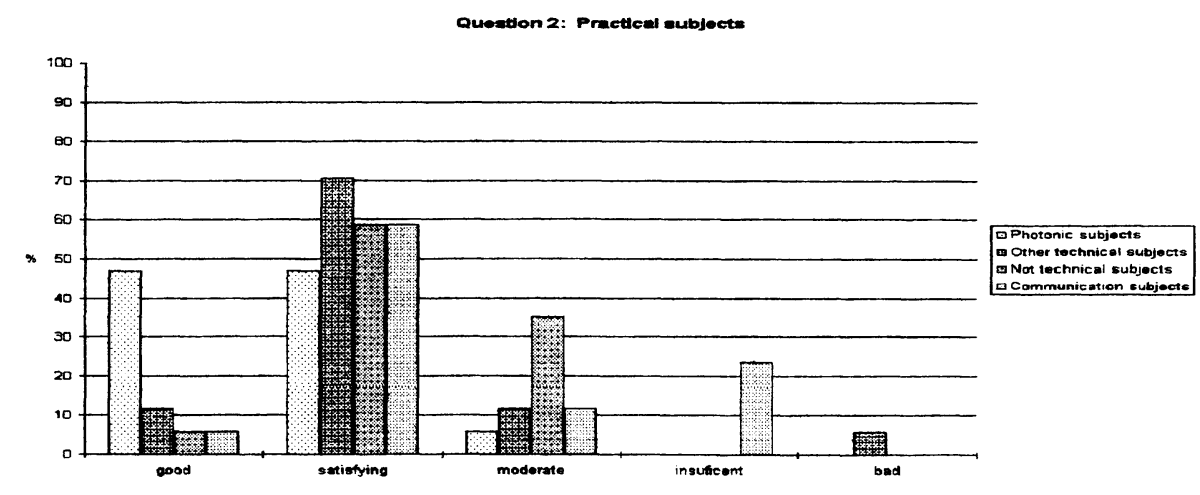

question 3: Give a judgement for mastering the details for a training period, graduation period, and/or employment.

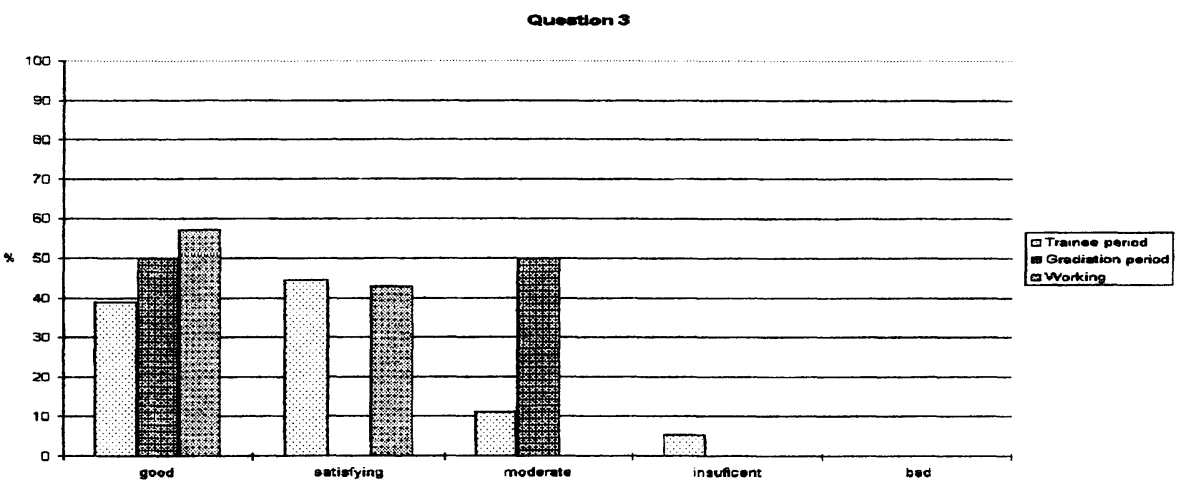

question 4: Give a judgement for the image created by the schools and how it agrees with your own expectations.

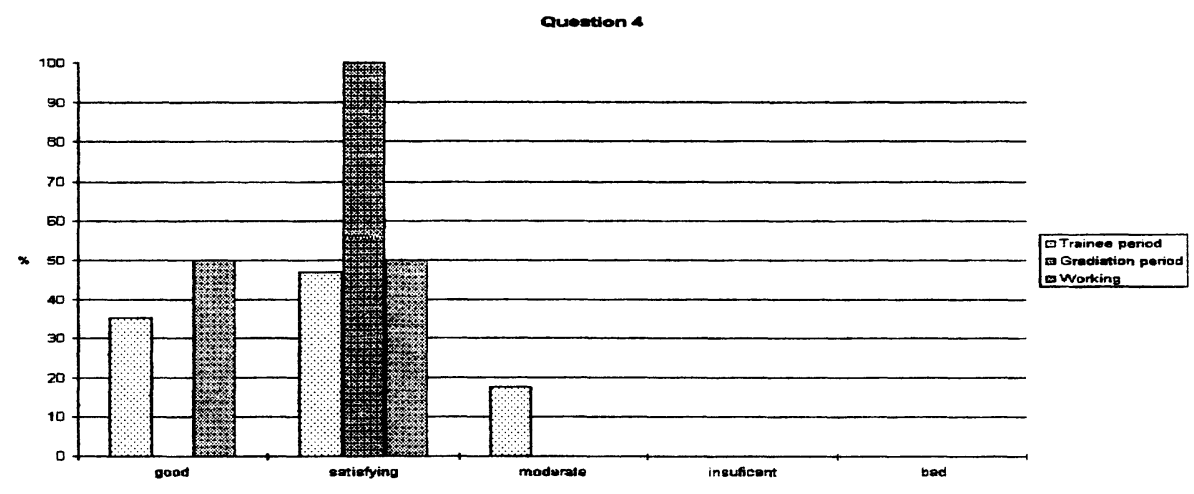




\subsection{Mentor form (MBO)}

question 1: Give a judgement for the time a trainee, graduate or employee needs for mastering the details during a training period, graduation period, and/or employment.

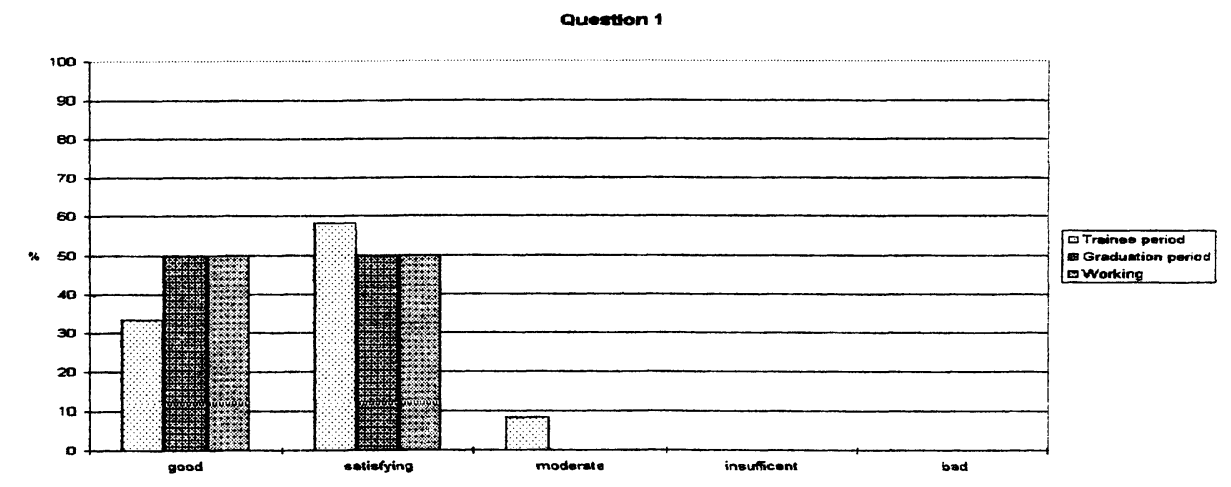

question 2: Give a judgement for the image created by the schools and how it agrees with your own expectations.

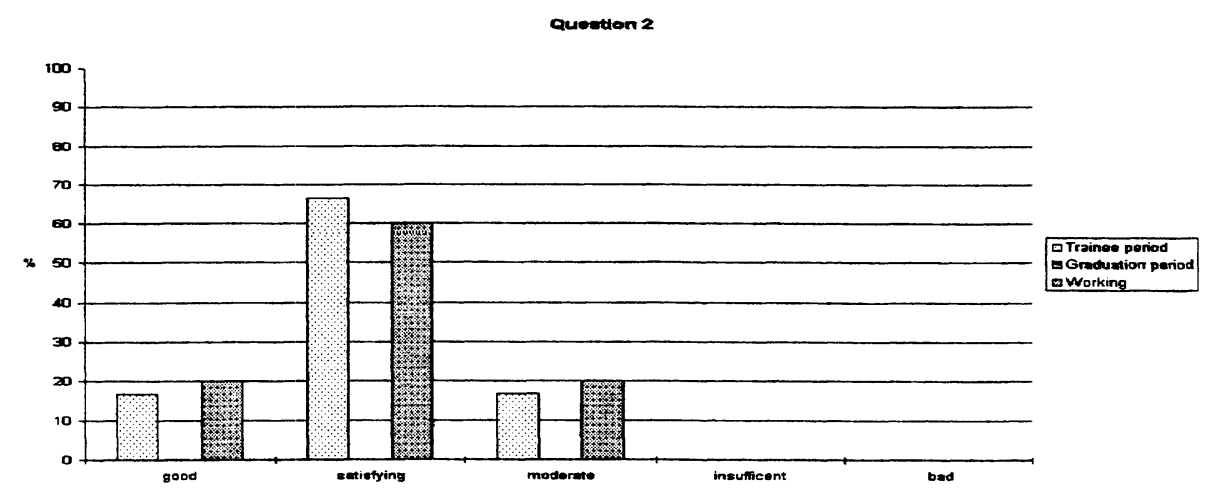

question 3: Give a judgement of the skills from a photonic trainee during trainee period and/or graduate period.

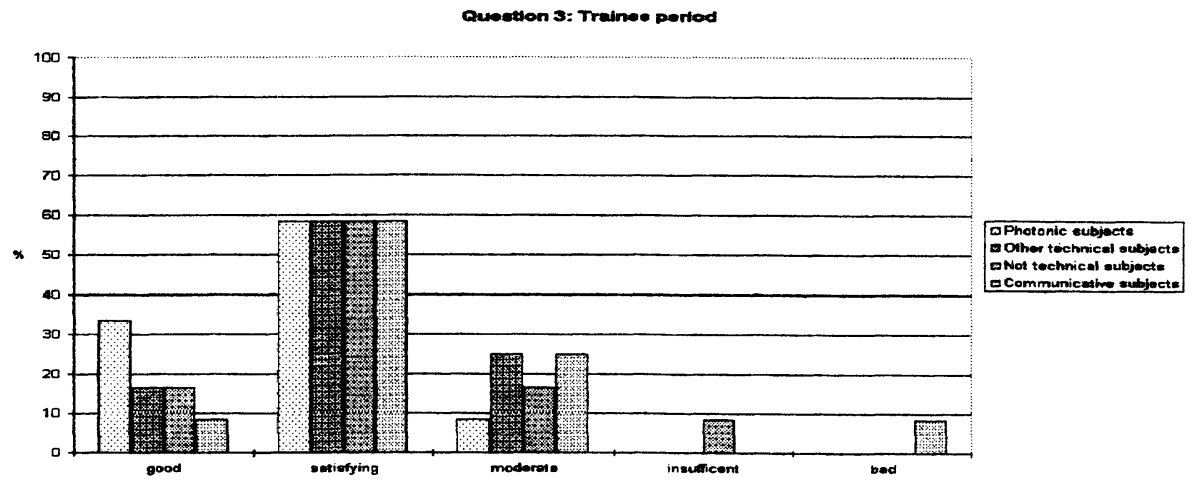




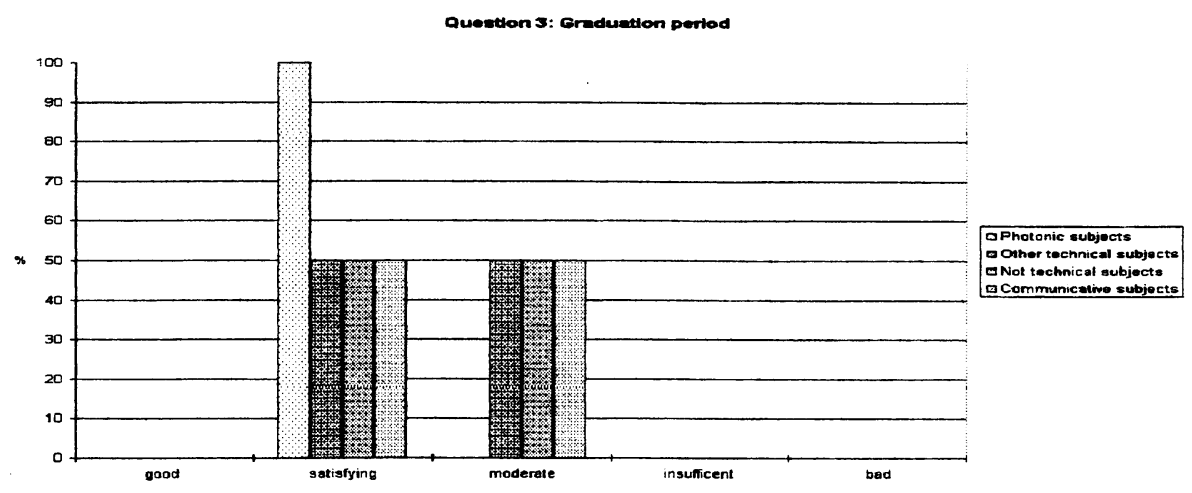

question 4: Give a judgement of the skills of a recent appointed photonic employee.

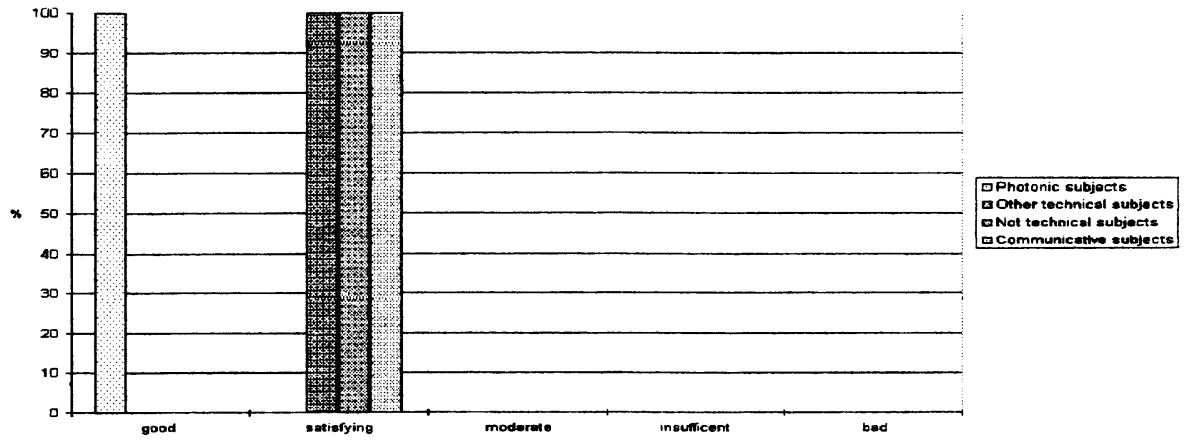

\subsection{Student/graduate form (HBO)}

question 1: Give a judgement of the given skills at the last followed "photonic" education.
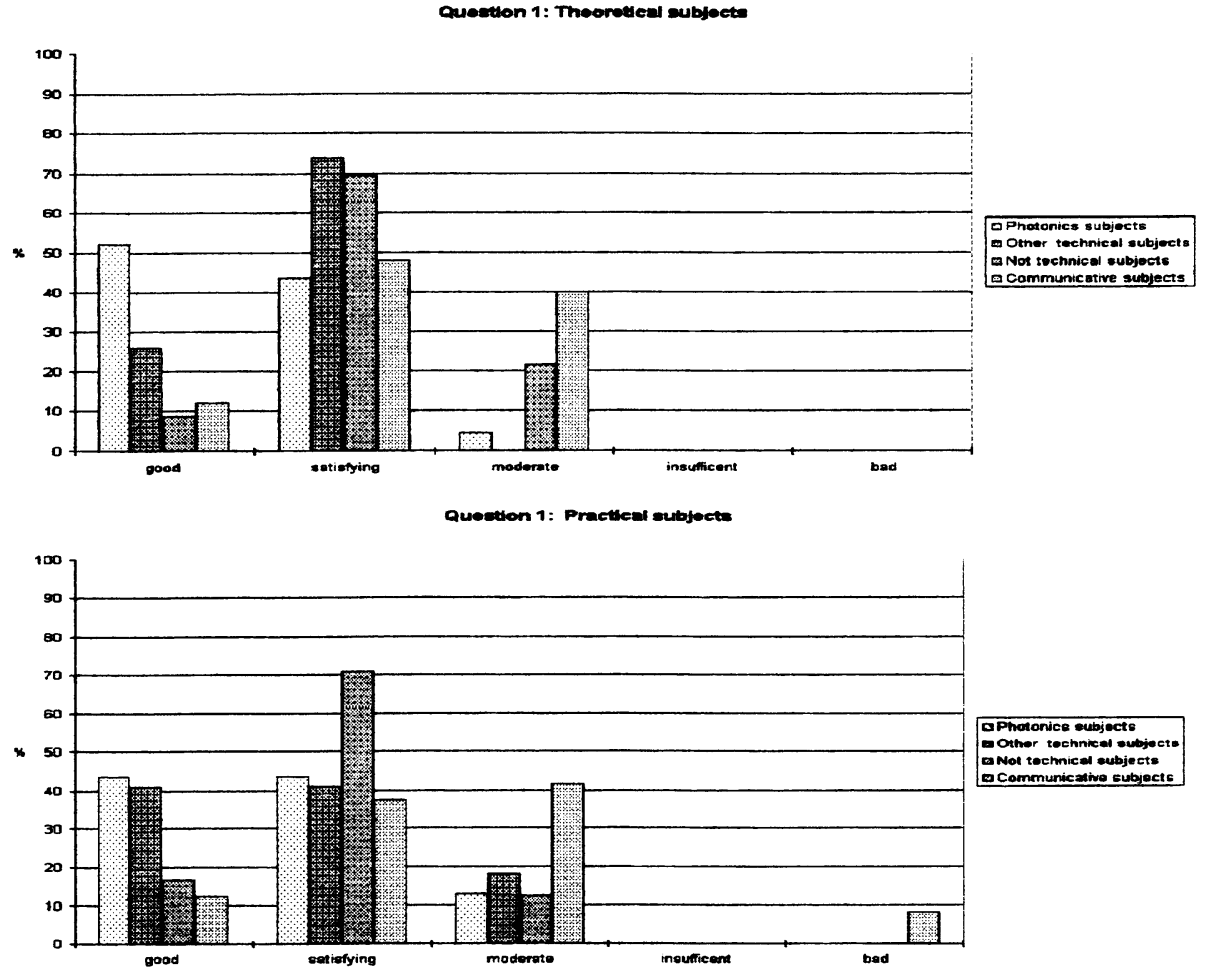

Ophotonice eubjocts

DOthor tochnicel subject
a Not tochnicel eubjects

andot tochnicel eubjects
ocommunicative subjects 
question 2: Which skills fit in with the trainee period, graduation period an during work.

Question 2: Theoretical subjects
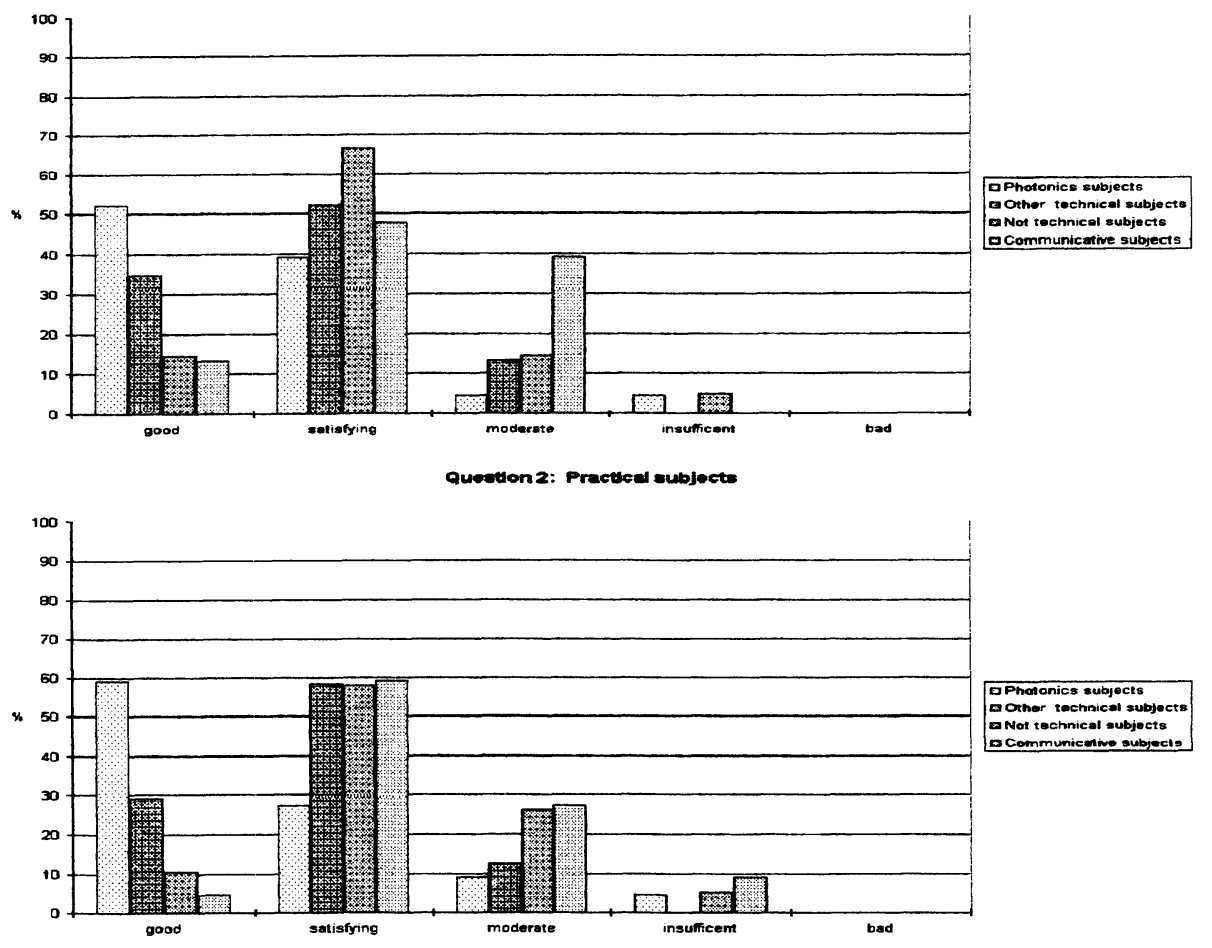

question 3: Give a judgement for mastering the details for a training period, graduation period, and/or employment.

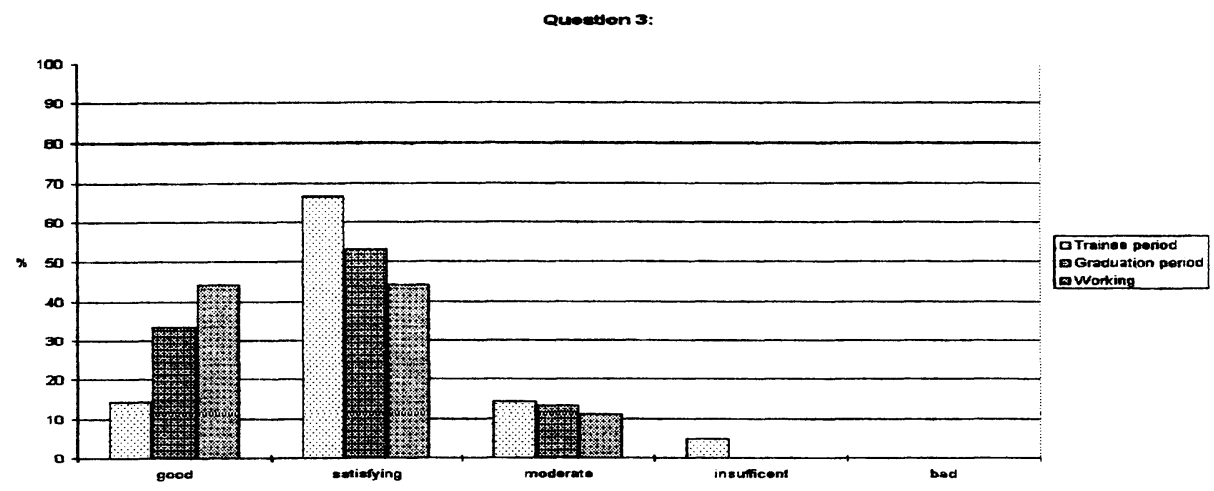


question 4: Give a judgement for the image created by the schools and how it agrees with your own expectations.

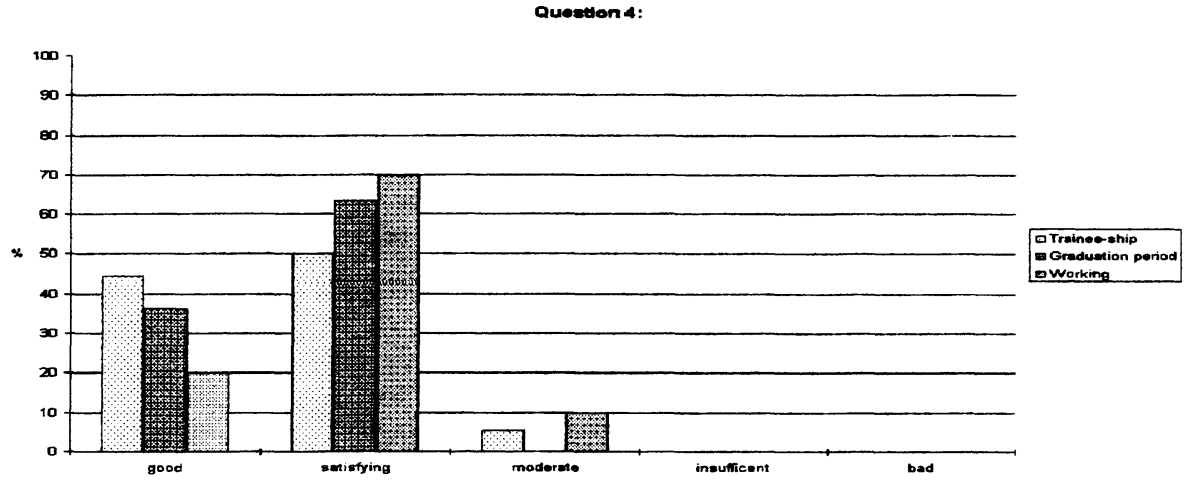

\subsection{Mentor form (HBO)}

question 1: Give a judgement for the time a trainee, graduate or employee needs for mastering the details during a training period, graduation period, and/or employment.

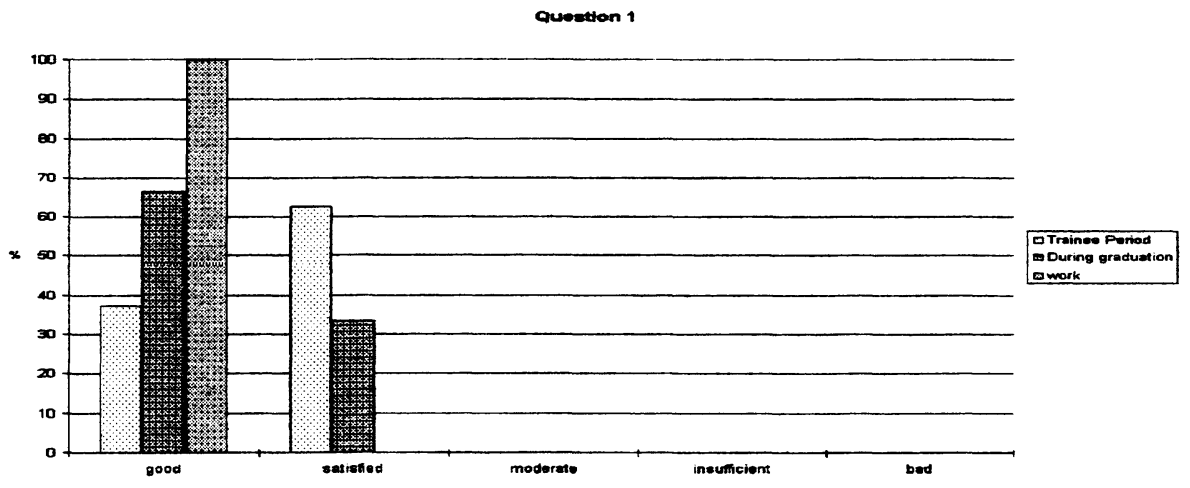

question 2: Give a judgement for the image created by the schools and how it agrees with your own expectations.

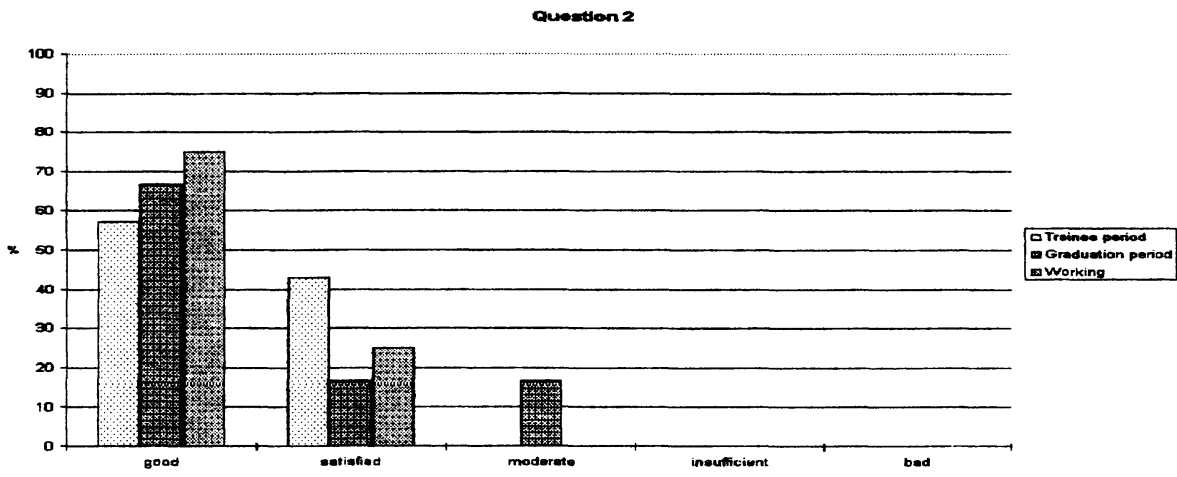


question 3: Give a judgement of the skills from a photonic trainee during trainee period and/or graduate period.

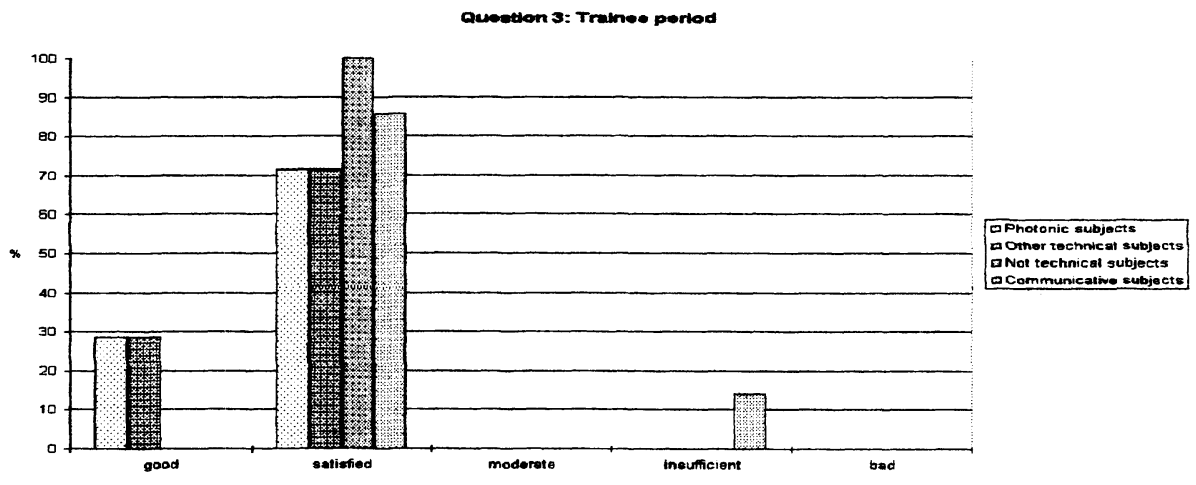

Question 3: Gractuation poriod

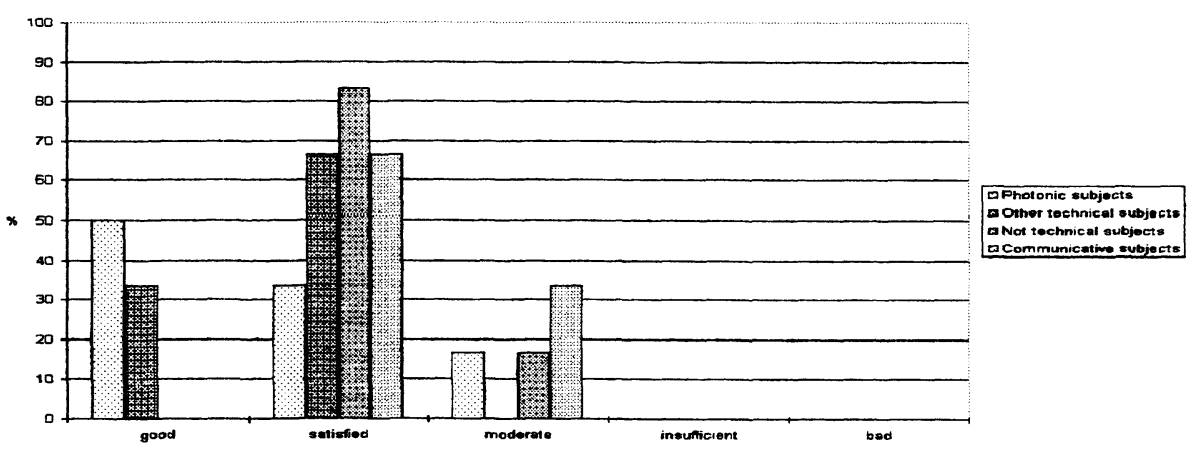

question 4: Give a judgement of the skills of a recent appointed photonic employee.

Quextion 4

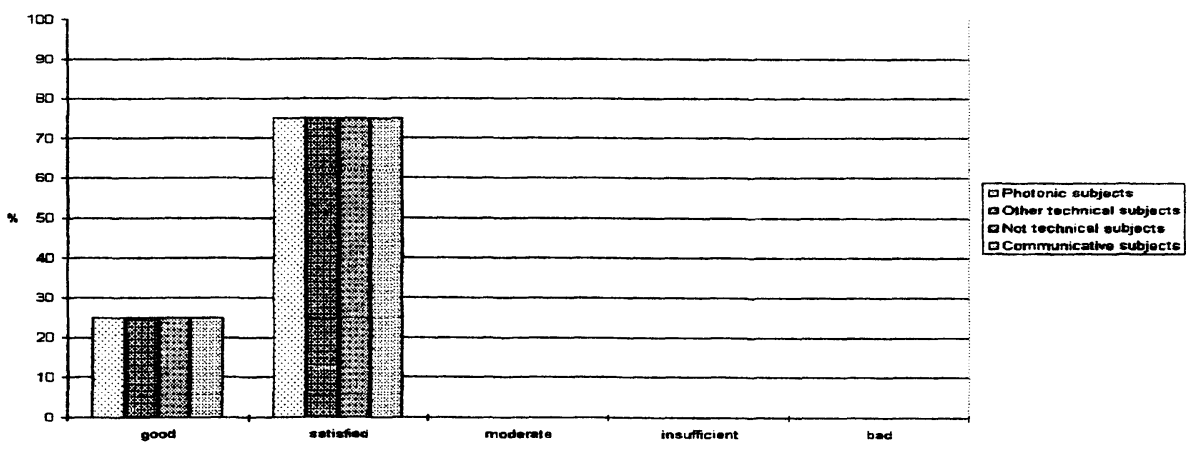




\subsection{Suggestions}

The authors are awere that we can't conclude anything from the given suggestions. The printed suggestions are the ones which appear frequently and are relevant.

\subsubsection{MBO}

Students want:

- more projects and practice

- $\quad$ more knowledge of the understanding of technical drawings

- more knowledge about up to date software

Mentors want:

- $\quad$ a better knowledge of making reports by students

- $\quad$ more knowledge about up to date software

\subsubsection{HBO}

Students want:

- $\quad$ training in application technics

- $\quad$ more knowledge of making reports

Mentors want:

- a better knowledge of making reports

\section{CONCLUSION}

Students and mentors at the MBO and HBO level are both satified with the connection between the schools and the trade and industry. The graphs (6) shows in general that the people are satisfied with the different skills, only the communicative skills are less aproved. Be aware that the population is limited. 


\section{REFERENCES}

[1] Bouts, F.A.J., De afstudeerrichting Fotonica van de Technische Hogeschool in Rijswijk, Nederlands Tijdschrift voor Fotonica, februari 1991.

[2] Brugmeijer, J.W, Hoe goed sluit het onderwijs in de optica en fotonica aan de behoufte van het bedrijfsleven in Nederland, Nederlands Tijdschrift voor Fotonica, juni 1991.

[3] Procee R, Fotonica op de Chr. MTS-Ede, Nederlands Tijdschrift voor Fotonica, december 1989.

[4] Procee $R$, Fotonica-onderwijs Technisch College Ede, Nederlands Tijdschrift voor Fotonica, oktober 1991

[5] Procee R, Drie jaar Fotonica op Technisch College Ede, Nederlands Tijdschrift voor Fotonica, augustus 1993.

\section{PARTICIPATING INSTITUTES}

Nederlandse Vereniging voor Fotonica (NVvF)

P. Menger

p/a Technische Hogeschool Rijswijk

Lange Kleiweg 4

2288 GK Rijswijk

Leidse Instrumentmakers School (LIS)

$P$. Junger

Nieuwsteeg 18

2311 SB Leiden

Hogeschool Utrecht

Dhr. Uiterwijk

Postbus 573

3500 AN Utrecht

Technisch College Ede (TCE)

H. Tuit

Bovenbuurtweg 7

6710 BL Ede

r.-k Technische Hogeschool Rijswijk (THR)

Studierichting Technische Natuurkunde

F. Bouts

Lange Kleiweg 4

2288 GK Rijswijk

Technisch Natuurkundige Studievereniging Ångström

P. Stroobach \& I.J. Boerefijn

Lange Kleiweg 4

2288 GK Rijswijk 